\title{
Evaluating the Role of Internal Factors in the Damage and the Methods of Treatment of the Limestone of Emir Hasan Mosque in Akhmim, Sohag, Egypt
}

\author{
Elashmawy A. Abd-Elkareem \\ Conservation Department, Faculty of Archaeology, South Valley University, Qena, Egypt \\ Email: elashmawyabdelkareem@yahoo.com
}

How to cite this paper: Abd-Elkareem, E.A. (2020) Evaluating the Role of Internal Factors in the Damage and the Methods of Treatment of the Limestone of Emir Hasan Mosque in Akhmim, Sohag, Egypt. Open Journal of Geology, 10, 1280-1295. https://doi.org/10.4236/ojg.2020.1012064

Received: December 3, 2020

Accepted: December 28, 2020

Published: December 31, 2020

Copyright (อ 2020 by author(s) and Scientific Research Publishing Inc. This work is licensed under the Creative Commons Attribution International License (CC BY 4.0).

http://creativecommons.org/licenses/by/4.0/ (c) (i) Open Access

\begin{abstract}
The present paper examines the deterioration of the limestone of Emir Hasan Mosque as a result of internal damage factors. Tests were done and carried to determine the rate of damage to the limestone that was used in the past in Egypt. Chemical analyses were done to identify soluble salts. The study utilized optical microscopy, scanning electron microscope equipped with EDS unit, and X-ray diffraction analysis to identify the main causes of increased limestone damage rates because of being affected by internal destructive factors. The study discussed different ways to conserve separate parts through the use of one consolidated material through the study of changes to limestone during the period of treatment to determine the appropriate treatment methods.
\end{abstract}

\section{Keywords}

Emir Hasan Mosque, Internal Factors, Damage, Limestone, Treatment

\section{Introduction}

Akhmim is an important area in Egypt. It contains many Pharaonic, Coptic, and Islamic buildings. Emir Hasan Mosque was built during the Ottoman era using stones of old buildings [1]. It has a square shape in the middle, holding its roof made of wooden blocks created by the bases and capitals and decorated by corners motifs. The roof of the mosque, decorated with color and writings, is the entrance to the mosque in the western end of the south-fronted entrance. The basement of the minaret is a square building with brick and an enveloped from 
abroad by limestone. The second floor of the minaret is octagonal, whereas the third floor has a cylindrical shape topped by the top of the minaret with an octagonal shape closer to rotation. The area contains the mosque at the shrine of Emir Hasan bin Amir Mohammad, the founder of the mosque who died in 1132 $\mathrm{AH}$. The shrine is recently renovated not related structurally to the mosque. Some parts of the tomb marble composition contain the name Emir Hasan and the date of his death, Figure 1(a).

That study was carried out on limestone that was one of the most important materials used in ancient buildings, especially the pyramids and temples [2]. It is known that one of the main causes of limestone damage is due to the internal factors of the limestone itself, such as the mineral composition and physical properties of the limestone. The presence of relative humidity and temperature, especially in the presence of uncontrolled environmental conditions played a role.

\section{Field Observations and Deterioration Causes}

It is known that limestone is relatively unstable in the face of accelerating damage factors, especially internal factors. When limestone is exposed to relative humidity and fluctuating temperatures, it gives patterns and degrees of damage that are somewhat similar in short periods. The study indicated that there are many main internal and external damage factors affecting limestone under study. Some causes of damage are evident in the high concentration of soluble salts, clay minerals in a large composition, and significantly accurate pores within the sandstone structure. Changes in the limestone's physical properties led to changes in its ability to withstand the damaged conditions [3] [4].

Dissolved salts are one of the most important factors of damage inside the porous materials, such as stones. The surface pattern and the patterns of erosion composition contribute well to the behavior of salts inside the stone in terms of the occurrence of a polished surface, deep cracks, fine cracks, expansion, turning

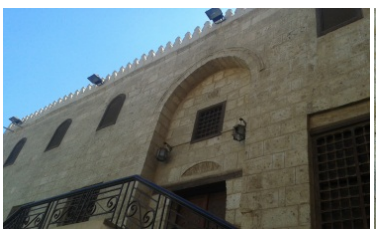

(a)

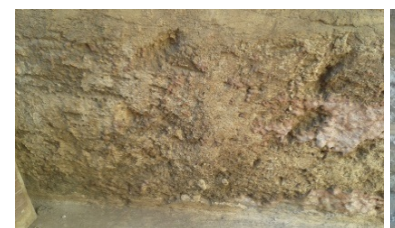

(d)

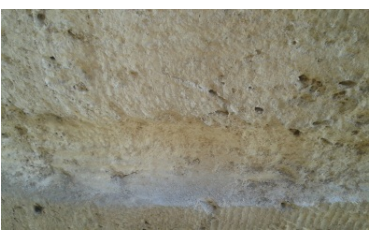

(b)

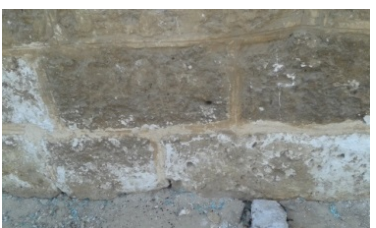

(e)

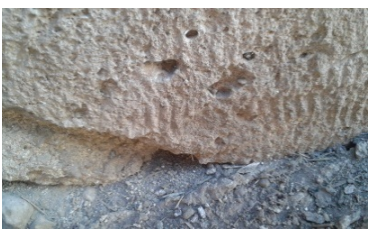

(c)

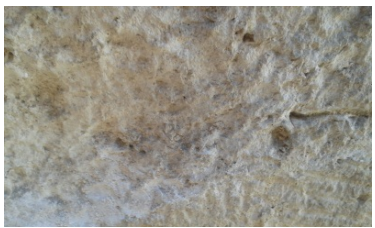

(f)

Figure 1. (a) A general view of Emir Hasan Mosque; (b, c, and d) The presence of cracking, pitting, loosening, and deformation of the limestone surface; (e and f) salt efflorescence leading to the deterioration of limestone. 
the surface into a soft powder or mortise, or granular dissolution. The dissolved salts damage the porous materials at a mechanical rate that contains physical pressure as a result of the crystallization and hydration of the salts, as well as the difference of the thermal expansion coefficient. Salts swell the clay for the stones that are rich in clay content, which accelerates the damage processes. Changes in relative humidity can cause salts through repeated cycles of hydration and crystallization. These effects take two different forms. The first is the efflorescence of salts, which are harmless, but not attractive to the sediments. It occurs during the crystallization of salts on the stone surface. It can occur under the surface to form what is called sub-surface efflorescence, which is the most dangerous to the stones. As for the other factors, they contribute to the damage system in the porous materials. This can be found in the presence of salts with a porous structure, which increases the effects of damage [5] [6].

The presence of a mixture of salts inside the formation of pores can affect the solubility of salt. Changes also depend on relative humidity and temperatures, which result in an increase in the crystallization cycles and hydration of the salts, depending on the porosity of the stone [7]. The porous system inside the stone extends to an area in which the processes of damage affect the limestone. Damage occurs in a large percentage of the fine pores in which the pore size is less than $5 \mathrm{~A}$ due to the mechanics of salt damage to a higher degree than those of the less extensive pores. The presence of clay as a compound among the components of the stones is one of the most important contributions to the internal stone damage [8] [9] [10] [11]. The internal clay components have cycles of swelling and shrinkage as a result of moisture and dehydration conditions that occur as a result of large changes in relative humidity. This, in turn, leads to stresses in the limestone structure leading to damage to the internal structure of the limestone. In addition, the presence of soluble salts contributes to the spread of clay [12].

Emir Hasan Mosque in Akhmim was exposed to the impact of groundwater from agricultural drainage and sewage. Limestone is strongly affected by various factors of weathering, especially in urban areas [13]. The effects of sulfate attack are very quick in some cases of damage to the stones. These rates increased over the past few periods. Salts, nitrates, sulfates, chlorides, and carbonates are the most common in the stones damage [14]. The most important limestone damage symptoms are gypsum, peeling, color change, and salt crystallization, etc.) [15]. The presence of gypsum in limestone is due to the existing $\mathrm{SO}_{2}$ pollution of the atmosphere or $\mathrm{SO}_{4}$ of mortar [16] [17]. Air pollution leads to the appearance of black crust on the surface of limestone and helps bacteria to dye the limestone in black. Increasing the surface water levels resulting from the lack of maintenance of drinking water and sanitation lines has a significant role to play [18]. Also, sodium sulfate plays a big role in the limestone damage, while magnesium sulfate affects a lesser extent [19]. Salts cause the disintegration of granules and some cracks as they lead to poor mechanical properties of limestone [20].

Damage operations start within the stones because of the interaction of mole- 
cules of water and stone surface by Van Der Waals forces [21] [22]. Clay minerals in limestone cause severe damage, through swilling and shrinking cycles of clay [23]. There is a task for bacteria within the limestone processing exhibition damage where they can form carbonate $\mathrm{CaCO}_{3}$. The size of the crystals depends on the bacteria strain [24]. The soluble salt moves the wet stone. On drying, the salt precipitates are out of solution into crystals either on the surface or within the pores of the stone. Crystallization within pore spaces can cause dislodgement of individual grains [25] [26] (granular disintegration) or the event of scales and flakes of stone Figures 1(b)-(e) [27]. Salt weathering is one of the foremost causes of the decay of natural stone [28].

Seasonal variations in temperature and humidity and atmospheric conditions govern the efflorescence of soluble salts [29]. Salt efflorescence also occurs as a result of changes in temperature and humidity. Limestone becomes susceptible to weathering when it is weathered and it is related to the permeability of the stone, its degree of water absorption, and its mechanical strength. [30]. In the presence of some deposits of halite salts and gypsum, they cause physical pressures [31].

By studying the building of Emir Hasan Mosque, it was found that limestone has been exposed to many different factors of damage, causing the deformation of the surface of the building through the accumulation of pollutants and dirt. This leads to an increase in the process of damage that occurs inside the limestone. The building has many manifestations of damage related to the activity of soluble salts in addition to the presence of clay minerals, as observed in the hardening of some surface layers Figure 1(d). This occurs when the strength of the bond between the granules is decreased, and the grains of limestone are weak. They result from the activity of salts, which may lead to the loss of some surfaces as a result of granular fragmentation. Many cracks were found perhaps as a result of the phenomenon of swelling and shrinkage of some of the clay components, which are produced related to the cycles of relative humidity. The thermal expansion affects the damage of limestone as it depends on the temperature cycles and the internal components of the limestone.

\section{Materials and Methods}

The study samples were collected by non-destructive methods from the archaeological building of Emir Hasan Mosque in Sohag.

\subsection{Petrographic Examination}

Polarized microscope units (LEV 100 POL) were used in the petrographic study of limestone samples by a Nikon polarized microscope.

\subsection{X-Ray Diffraction (XRD)}

XRD Unit, Faculty of Science, Assuit University, Model PW 1710 control unit Philips, $2 \theta$ from 4 to 60, Anode Material Cu, 40 K.V, 30 M.A. 


\subsection{Chemical Study by XRF}

Identifying the chemical composition of all samples of limestone was carried out in the Central Lab, South Valley University by X-ray Fluorescence Analysis (XRF), JEOL JSX Element Analyzer with Energy Dispersive X-Ray Fluorescence system (EDXRF).

\subsection{Scanning Electron Microscope (SEM)}

SEM was carried out in the Central Lab, South Valley Univ. using JEOL JSM-5500 LV SEM (JEOL, Japan).

\section{Results}

\subsection{Petrography Investigation}

The microscopic study of the limestone samples under the polarized microscope showed the surface shape of the grains and some fine cracks, as well as some of the grains in powder form (Figure 2). Some details about the porosity were also shown.

\subsection{Mineralogical Analysis by XRD}

Calcite was found as the major compound in addition to the presence of secondary compounds, such as quartz and gypsum. The X-ray diffraction analysis did not reveal the presence of clay minerals or aluminum silicates obtained by the scanning electron microscope. It also showed the presence of soluble salts in small proportions, such as halite and chloride as a result of the damage to the limestone Figures 3-5, Table 1, Table 2.

Table 1. The percentage of the compounds of the sample of Emir Hasan Mosque.

\begin{tabular}{cc}
\hline Whole rock mineral & Mineral \% \\
Calcite & 89.5 \\
Clay & 1.5 \\
Quartz & 2.4 \\
Gypsum & 2.7 \\
Amorphous materials & 3.9 \\
\hline
\end{tabular}

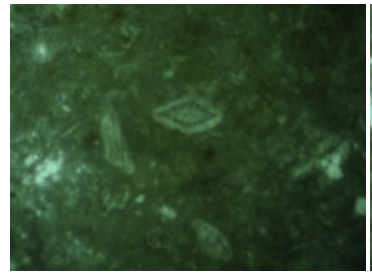

(a)

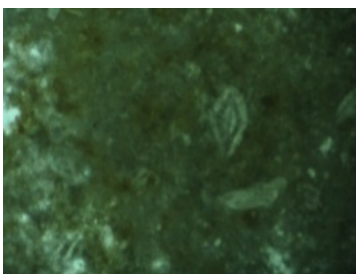

(b)

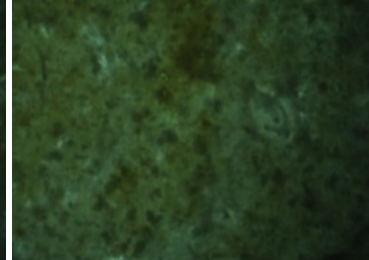

(c)

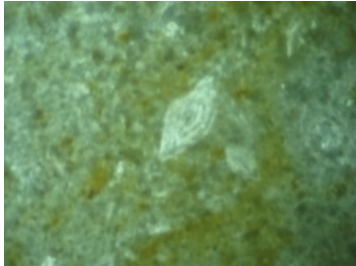

(d)

Figure 2. (a, b, c \& d) shows the presence of some or parts of fossils, especially the nemolite, which consists of calcite between grains of limestone. Dolomite was found filling some cracks. Gypsum and calcite are the main mineral compounds. 

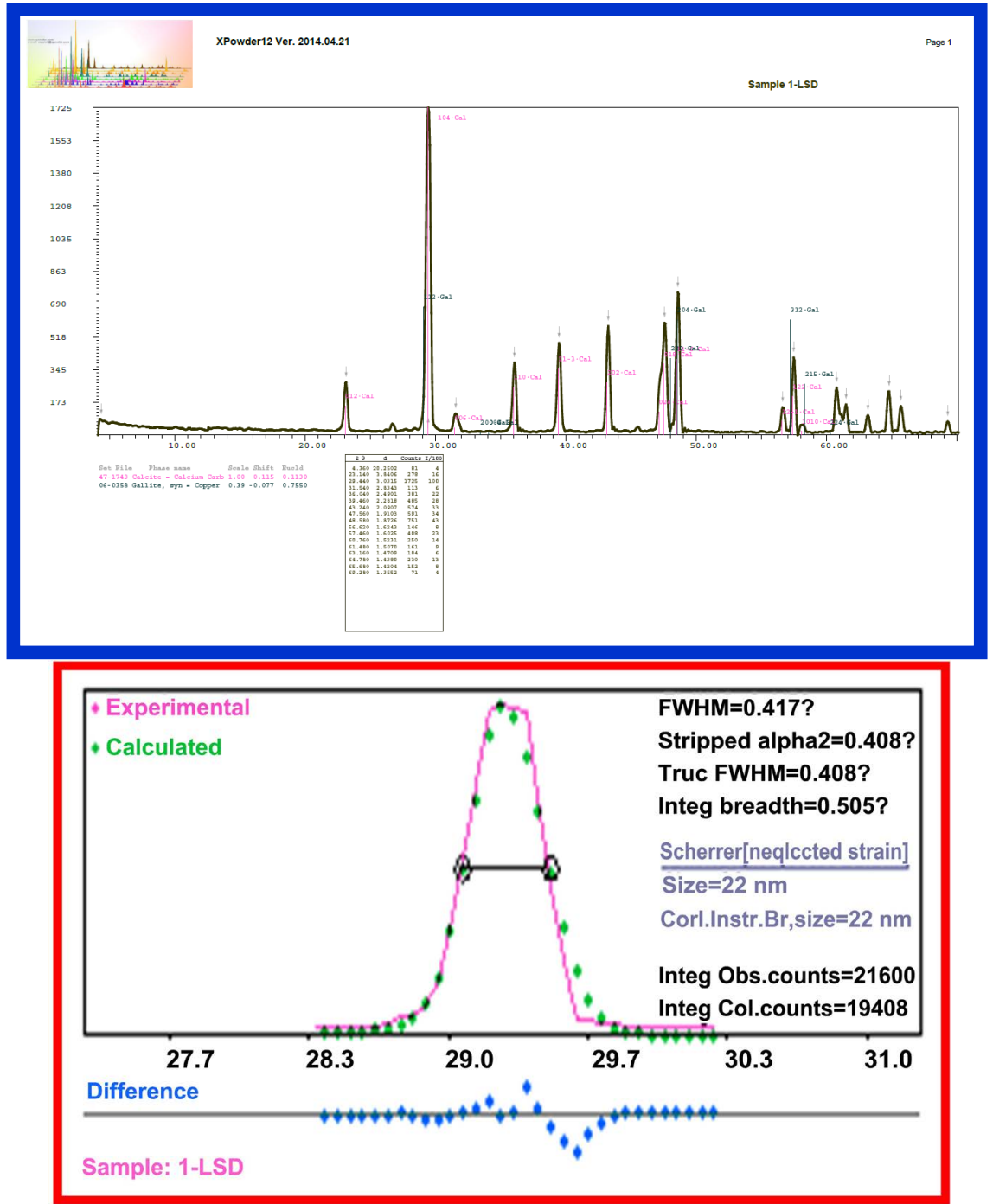

Figure 3. XRD pattern of the sample of Emir Hasan Mosque.

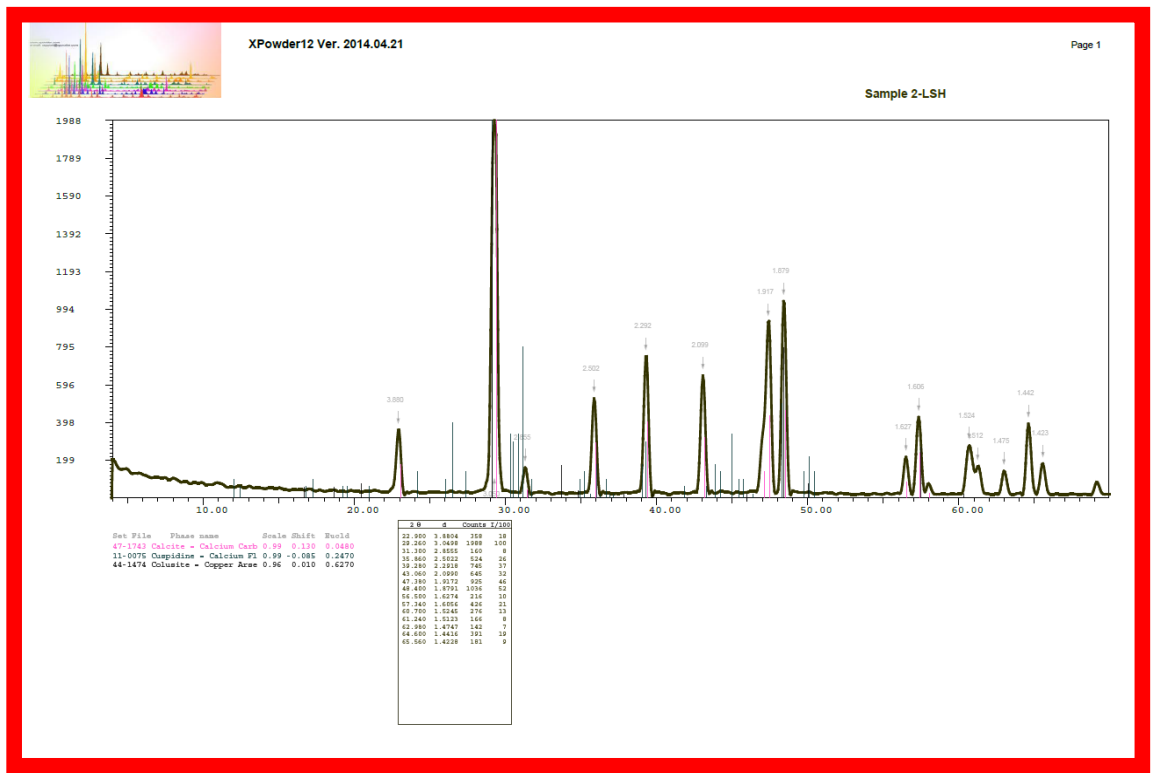




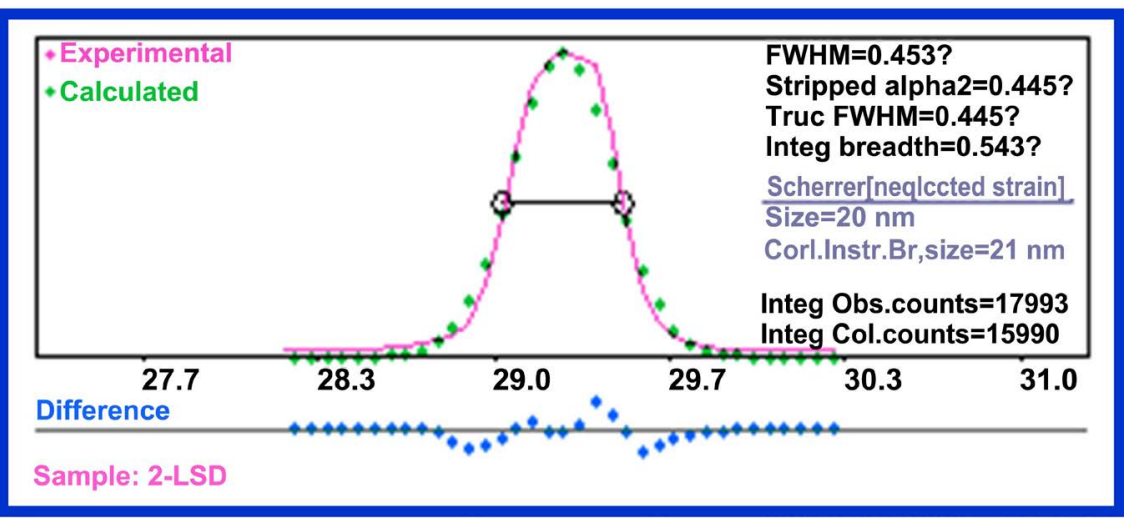

Figure 4. XRD pattern of the sample of Emir Hasan Mosque.

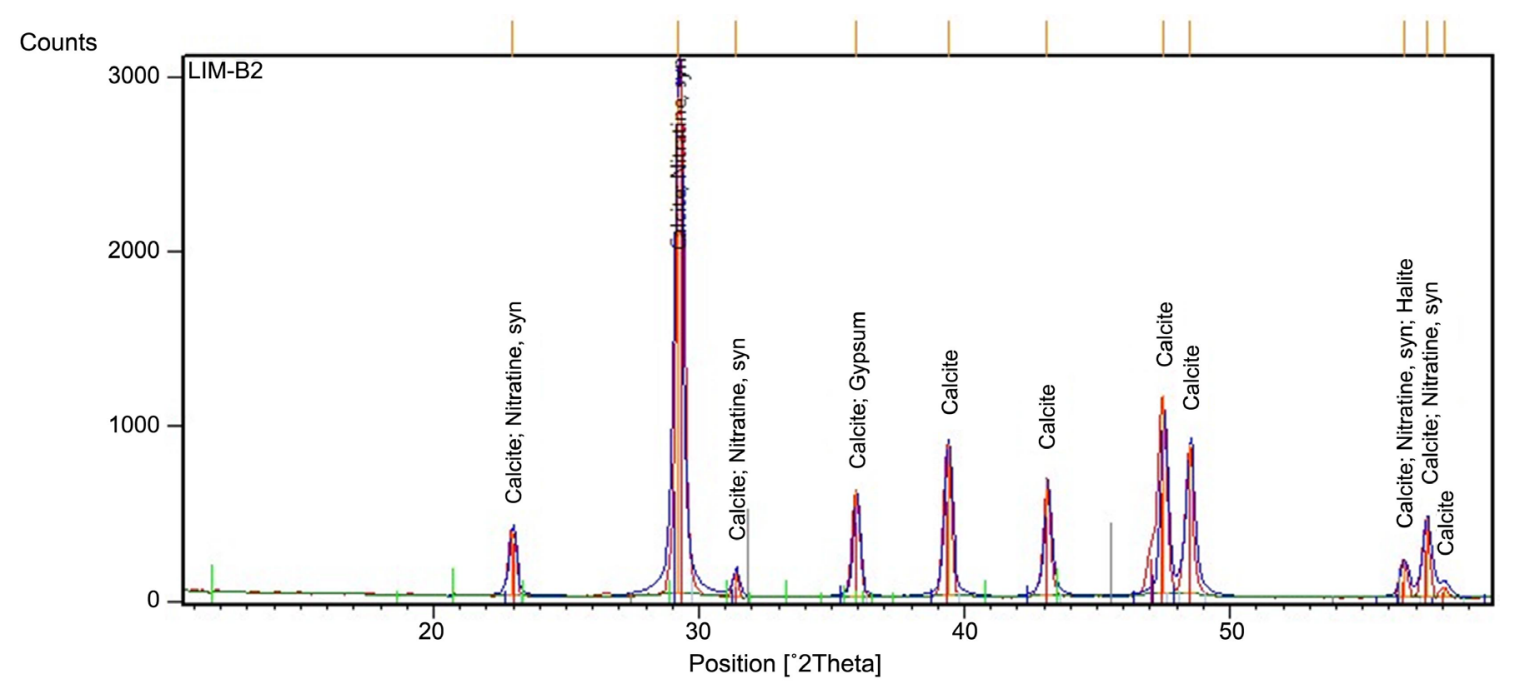

Figure 5. XRD pattern of the sample of Emir Hasan Mosque. Nitratine: $\mathrm{NaNO}_{3}$.

Table 2. The percentage of the compounds in the sample of Emir Hasan Mosque.

\begin{tabular}{cc}
\hline Whole rock mineral & Mineral \% \\
\hline Calcite & 88.6 \\
clay (Kaolinite) & 7.8 \\
Quartz & 2.4 \\
cuspidine & 1.2 \\
\hline
\end{tabular}

Cuspidine: Calcium Flouride Silicates.

\subsection{Chemical Analysis by XRF}

The chemical analysis of the limestone samples revealed the decrease of the content of $\mathrm{SiO}_{2}$ (0.53 - $\left.0.51-0.50\right), \mathrm{AI}_{2} \mathrm{O}_{3}(0.14-0.16-0.18)$, and $\mathrm{MgO}(0.11-0.12$ $0.11)$. It also showed the increase of the content of $\mathrm{CaO}(56.46-56.42-56.32)$, $\mathrm{SO}_{3}\left(0.14-0.13\right.$ - 0.16), $\mathrm{P}_{2} \mathrm{O}_{5}(0.07-0.05-0.08)$, and $\mathrm{Fe}_{2} \mathrm{O}_{3}(0.05-0.04-0.02)$. Gypsum forms when $\mathrm{CaCO}_{3}$ reacts with $\mathrm{SO}_{2}$. The results of the chemical analysis showed that all samples are positive for chloride salts and negative for nitrate and sulfate salts. 


\subsection{Scanning Electron Microscope (SEM) with the EDS Unit}

Figure 6(a) and Figure 6(b) show the details of the outer surface. Small and semi-round white particles were found. The initial analysis showed the presence of calcium, oxygen, and carbon in most of the molecules, which is likely to be calcium carbonate, Figure 6(c) and Figure 6(d). Also, these particles appeared in a degraded and weak state as they do not bind to the cement to a large extent. The ADS analysis revealed a high percentage of chloride and sodium Figure 6(a).

Silicon and aluminum were also observed, indicating aluminum silicate minerals, clay minerals, in the form of flakes between the white particles. Some parts of the fossils spread in all parts of the texture of the limestone, indicating the origins of the limestone as confirmed by the petrographic study of limestone sectors using the polarized microscope, Figure 6(c). Calcium was also evident in the white areas, indicating the presence of calcite, as shown in Figure 6(a). The presence of calcium and silicon suggests clay mineral particles.

\section{Discussion}

Samples of the limestone of Emir Hasan Mosque, Akhmim consist of calcite $(88.6 \%-89.5 \%)$, gypsum $(2.7 \%)$, quartz $(2.4 \%)$, clay materials $(1.5 \%-7.8 \%)$, amorphous materials (3.9\%), and cuspidine (1.2\%) (Table $1 \&$ Table 2 ) and (Figures 3-5). Calcite units in this building are very close to the typical dimensions of calcite mineral in theory (Figure 2). The correlation of calcium with magnesium in calcite units is very low. Moreover, damage is manifested in the mosque, including peeling, erosion, loss of some stone parts, salty weathering, color change, and crusting due to some solid surface layers as a result of a change in composition (Figure 1(b)). The presence of a chemical or physical substance and color change may occur as a result of the growth of some microorganisms (Figure 1(d)). Thus, limestone loses the cohesion and bonding between its grains. There is dirt on the stone surface. The presence of clay particles or dust causes color change to the limestone surface of Emir Hasan Mosque. Groundwater has a great impact on limestone due to weak water and sanitation networks in the study area. Also, saline weathering is one of the most dangerous damaging effects on limestone through the efflorescence of salts and the formation

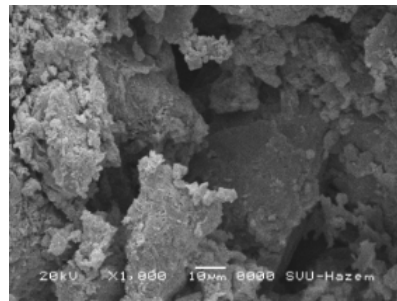

(a)

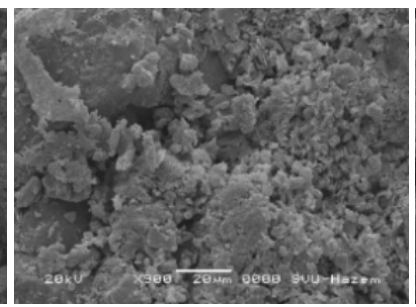

(b)

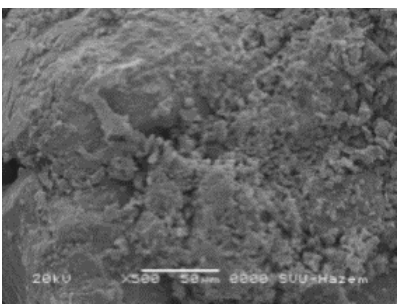

(c)

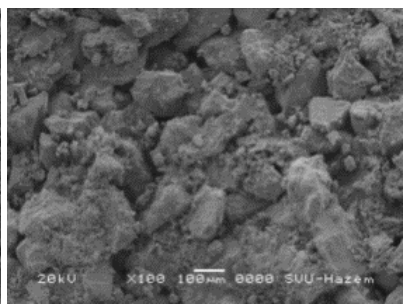

(d)

Figure 6. (a) The presence of secondary calcite as a result of the dissolution process, (b) The resulting damage and new layers covering the pores with limestone, (c) Salt crystals on limestone and deformation of the incident crystals, (d) Micropores and internal damage to limestone granules. 
of a salt crust. It causes the color change of the surface of the limestone in the study area (Figure $1(\mathrm{e})$ ).

Such manifestations might result in superficial crusting, which led to an internal collapse in the limestone structure. By examining the damaged samples, a high porosity was observed with a high percentage of clay with iron oxides and gypsum. The petrographic study also indicated the decomposition of the surface layers that absorbed the existing clay minerals. In limestone, the flow of water from the crystallized clay led to the swelling of the clay particles. When water is absorbed, it leads to small cracks inside the limestone building as a result of changes in temperature, relative humidity, the migration of dissolved salts in groundwater to limestone, the weakness of limestone's ability to absorb water. Internal damage to limestone occurs in the form of small internal cracks. The study of the examinations with the scanning electron microscope also showed that the clay minerals covered the calcite grains, and many pores were observed in the presence of dissolved calcite granules and separate fine clay granules. Furthermore, there were some separate granules and tiny pores due to the damage of some calcite grains. Therefore, the cohesion between the grains was lost in addition to the growth of gypsum granules. Superficial damage to limestone occurred as a result of salt crystallization. Some parts of the limestone were damaged because of the presence of dust on their surface or between the grains. Additionally, halite salt that spreads in the Egyptian soil was observed. Having anhydrite and gypsum salts indicates the presence of a sulfur ion as a result of microbiological activity or air pollution. The rate of damage increases with successive cycles of moisture and dryness in the presence of microcracks. Accordingly, the physical properties of the stone changed.

The presence of water in the stone pores is one of the most important sources of damage. The chemical analysis, shown in Table 3 shows that there is a difference in the ratios of the elements that caused damage (i.e., $\mathrm{AI}_{2} \mathrm{O}_{3}, \mathrm{SiO}_{2}, \mathrm{SO}_{3}$, and $\mathrm{Fe}_{2} \mathrm{O}_{3}$ ), which are proportional to the basic oxide in the building material (i.e., $\mathrm{CaO})$. The proportions of these materials indicated oxides to the extent of the various mechanical damages that cause limestone: $\mathrm{Fe}_{2} \mathrm{O}_{3}(0.05 \%-0.04 \%$ $0.02 \%), \mathrm{AI}_{2} \mathrm{O}_{3}(0.14 \%-0.16 \%-0.18 \%), \mathrm{SiO}_{2}(0.53 \%-0.51 \%-0.50 \%), \mathrm{SO}_{3}$ $(0.14 \%-0.13 \%-0.16 \%)$ compared with basic oxide $\mathrm{CaO}(56.46 \%-56.42 \%-$ $56.32 \%)$. The presence of these oxides in these proportions resulted from the impact of dirt, dust, and air pollutants on the limestone.

The changes in the quantity and the method of classifying the different oxides have a role in the processes of damage: $\mathrm{Na}_{2} \mathrm{O}(0.46 \%-0.48 \%-0.45 \%) \mathrm{Cl}(0.36 \%$ - $0.38 \%-0.33 \%)$, and $\mathrm{K}_{2} \mathrm{O}(0.05 \%-0.06 \%-0.03 \%)$ in comparison with the basic oxidation of the building $\mathrm{CaO}(56.46 \%-56.42 \%-56.32 \%)$. Some elements may be salts $(\mathrm{Na}, \mathrm{K}$, and $\mathrm{Cl})$. These differences may result from the exposure quarantine for the cycles of humidity and drought due to the effects of changing temperature and relative humidity depending on its sources, such as groundwater and sewage. Some forms of damage may be caused by random daily activities. Many results of the X-ray diffraction analysis agreed with the findings of the 
Table 3. Chemical analysis of 3 limestone samples by XRF.

\begin{tabular}{|c|c|c|c|}
\hline Main Constituents Wt\% & $\begin{array}{c}\text { Emir Hasan Mosque } \\
\text { limestone (a) }\end{array}$ & $\begin{array}{c}\text { Emir Hasan Mosque } \\
\text { limestone (b) }\end{array}$ & $\begin{array}{c}\text { Emir Hasan Mosque } \\
\text { limestone (c) }\end{array}$ \\
\hline $\mathrm{SiO}_{2}$ & 0.53 & 0.51 & 0.50 \\
\hline $\mathrm{TiO}_{2}$ & 0.01 & 0.02 & 0.01 \\
\hline $\mathrm{AI}_{2} \mathrm{O}_{3}$ & 0.14 & 0.16 & 0.18 \\
\hline $\mathrm{Fe}_{2} \mathrm{O}_{3}$ tot. & 0.05 & 0.04 & 0.02 \\
\hline $\mathrm{MgO}$ & 0.11 & 0.12 & 0.11 \\
\hline $\mathrm{CaO}$ & 56.46 & 56.42 & 56.32 \\
\hline $\mathrm{Na}_{2} \mathrm{O}$ & 0.46 & 0.48 & 0.45 \\
\hline $\mathrm{K}_{2} \mathrm{O}$ & 0.05 & 0.06 & 0.03 \\
\hline $\mathrm{P}_{2} \mathrm{O}_{5}$ & 0.07 & 0.05 & 0.08 \\
\hline $\mathrm{SO}_{3}$ & 0.14 & 0.13 & 0.16 \\
\hline $\mathrm{CI}$ & 0.36 & 0.38 & 0.33 \\
\hline LOI & 41.59 & 41.60 & 41.78 \\
\hline $\mathrm{Cr}_{2} \mathrm{O}_{3}$ & --- & $\ldots$ & $\ldots$ \\
\hline $\mathrm{MnO}$ & 0.015 & 0.016 & 0.015 \\
\hline $\mathrm{NiO}$ & 0.002 & 0.002 & 0.001 \\
\hline $\mathrm{CuO}$ & --- & $\ldots$ & $\ldots$ \\
\hline $\mathrm{Y}_{2} \mathrm{O}_{3}$ & --- & $\ldots$ & $\ldots$ \\
\hline $\mathrm{ZrO}_{2}$ & --- & $\ldots$ & $\ldots$ \\
\hline $\mathrm{SrO}$ & 0.013 & 0.012 & 0.012 \\
\hline
\end{tabular}

$\mathrm{XRF}$ analysis of the products of damage. For instance, calcite was observed as the main mineral in various samples.

\section{Conclusions}

Limestone is subjected to an increased rate of deterioration, especially in open places [32]. The presence of clay materials in limestone causes various damage and cracks as a result of swelling and shrinkage, depending on the degree of relative humidity at the site or through direct contact with water [33]. Air pollution, various sources of moisture, and many destructive human activities are considered, whether unintended or intentional. Also, the crystallization of salts on the surface of limestone or under its surface is one of the most important factors of limestone damage [34].

By examining the limestone of Emir Hasan Mosque, different types of damage were found as a result of the excessive salt activity observed through tests and analyses, which resulted in ripples on the surface and the separation of granules. Moreover, limestone fragments transformed into powder in the presence of a salt material and various visible fissures with salt crystals. This visual evidence on the surface of the stone was also confirmed by chemical analyses, such as the 
$\mathrm{X}$-ray diffraction, polarized microscopy, and scanning electron microscope equipped with the EDS unit. They all showed that limestone contains aluminum silicate compounds and dissolved salts. Additionally, a large proportion of calcite was observed. Studying the results of the X-ray diffraction and the petrographic study of the stone surface showed small cracks on the limestone tissues, which had fragmentation and separation from calcite particles due to the damaging activity of salts.

The results of this study confirmed the importance of preserving the Mosque within safe borders. Studying the limestone of Emir Hasan Mosque showed the extent of damage to the archaeological limestone under suitable environmental conditions based on the acceleration degree. The maintenance of limestone exposed to damage is a problem due to conducting a few studies only, especially on the study area. The study also highlighted the importance of the different treatment methods, such as reducing the salt content. It is also not preferable to remove salts from weak stones directly because they can pose damage to the weak damaged structures that must be strengthened. Then, work could be done to reduce and remove dissolved salts. This was preceded by the removal of dirt, which was done very carefully as permitted by the state of damaged limestone.

\section{Recommended Conservation Plan}

The conservation of a mosque constructed of limestone is carried out by reducing the influences of environmental factors causing deterioration. The rates of damage to the limestone can be prevented or reduced. The analyses showed that limestone contains high dissolved salts. Therefore, the presence of high levels of dissolved salts leads to an acceleration of the process of damage, even if suitable environmental conditions are provided as long as the damaged work continues [35] [36]. To reduce the effect of dissolved salts, it is necessary to reduce the salt content in limestone by using base water or using poultices [37] [38].

It was found that parts of the mosque's limestone are highly susceptible to damage, indicating the risk of using the base water on the outer and inner surfaces of damaged mosque stones. Using water directly on the surface of the limestone may lead to increased rates of damage [39]. Therefore, strengthening works should be undertaken to improve the chemical properties of limestone and stabilizing the separate limestone parts. In this manner, limestone could receive various treatments, such as consolidate the internal structure in the limestone structure and increasing the bonding strength between the grains. It also allows the possibility of using treatments with base water safely. Damaging to the external and internal structure of the limestone should be resolved by choosing the consolidation materials that match the physicochemical properties of limestone [40]. Silane or alkoxy silane compounds are suitable for limestone strengthening works as they give good permeability and porosity that allows the restoration of the limestone [41] [42]. The main goal of the use of alkoxy silanes is to strengthen the limestone due to weak chemical bonds because the bond that arises with the limestone tissue is basically physical. consolidation materials ir- 
regularly penetrate the limestone structure on the surfaces of the limestone grains where the physical bond is weak compared to the chemical one [43]. Therefore, Alkoxy silane can be used on damaged limestone surfaces because it gave good results in many previous studies according to Wheeler 2005 [44].

The preservation process is carried out depending on the extent of penetration and depth of the reinforcing material to improve the internal composition. The percentage of salts is reduced by using Poultices while working to improve the environmental conditions in which the mosque is located. Moreover, conservation work carried out continuously under these perishable environments is ineffective to an adequate degree in the future [45]. A treatment plan can be used for the mosque because limestone has many aspects of damage, such as separating some surface parts and covering the surface with soil and dirt. The removal of dirt on the surface of the limestone is also very important because this helps in the success of the treatment processes by increasing the capacity and effectiveness of the materials used in the treatment. The plan also helps clean the stone surface, making it more visible and highlighting the artistic elements. It is also preferable to clean dust by using soft brushes that do not affect the stone surface. The separate stone parts are also fixed. It should be noted that these separate stone parts are very weak and handled with a high degree of craftsmanship. After the completion of integrating the separate stone parts on the surface of the stone, surface dirt is removed using wet cleaning. It is also preferable to use Paraloid B. 72 of $5 \%$ weight/volume in an organic solvent, such as ethanol or acetone. Paraloid B. 72 is used due to its good adhesive properties, and it is suitable for use with alkoxy silanate. It is recommended for consolidating limestone [46].

The surface dirt is removed with ethyl alcohol by dipping a cotton swab wrapped over a swab in $100 \%$ ethyl alcohol. Poultices of cotton and wool impregnated with ethyl alcohol can be used and placed on the stone surface to be cleaned. The poultices are covered with a plastic sheet for several minutes so that the ethyl alcohol can penetrate the dirt and loosen its bond with the stone surface. It is also recommended to use tetra hydroxy silane TEOS due to its suitable properties for limestone. BSOH100 known as Wacher OH100 with MSDS catalyst is used. The application is also carried out by preparing the stone surface to be treated using a consolidate by drying it with acetone because the presence of water has a negative effect during the polymerization process. The hardener is used in its concentrated form because limestone can absorb the solids well.

Limestone consolidate is applied in three stages, each of which is 10 minutes. The duration of each session ranges from 30 minutes to one hour until the strengthening process is accomplished. The penetration of the stiffeners into the limestone is observed by following the side edges and the beginning of the appearance of some wet lines moving slowly down. After the completion of the consolidation process, the excess consolidates are removed by using a piece of cloth or blotting paper. The best conditions for consolidation operations are the temperature of $20^{\circ} \mathrm{C}$ and the relative humidity of $53 \%$. The best conditions for the silane material solidifies are the temperature of $10^{\circ} \mathrm{C}$ and the relative humid- 
ity of $40 \%$ according to MSDS 2008. The treated areas are left for $7-8$ weeks for the polymerization process to complete. A week after the completion of the polymerization process, the stone surfaces are prepared and the salts are removed after consolidation process. Furthermore, the base water treatment is prepared by the poultice method, which is made of pulp and has good absorption properties. Before the use of the poultice, the stone surface is moistened lightly with wet pressure applied to the compress. Then, a layer of plastic is placed on the compress so that the degree of evaporation from the compress is reduced to be done well. These compresses are replaced. After testing the degree of concentration of salts absorbed by the substance and reaching the lowest rate and stability, the poultices work is stopped and the poultice site is cleaned with distilled water according to [47].

\section{Conflicts of Interest}

The author declares no conflicts of interest regarding the publication of this paper.

\section{References}

[1] Geens, K. (2007) Panopolis, a Nome Capital in Egypt in the Roman and Byzantine Period (ca. AD 200-600). PhD Thesis, Catholic University of Leuven, Leuven, 15.

[2] Klemm, D. and Klemm, R. (2001) The Building Stones of Ancient Egypt-A Gift of Its Geology. Journal of African Earth Sciences, 33, 631-642. https://doi.org/10.1016/S0899-5362(01)00085-9

[3] Siegesmund, S., Sousa, L. and López-Doncel, R.A. (2018) Editorial to the Topical Collection in Environmental Earth Sciences "Stone in the Architectural Heritage: From Quarry to Monuments-Environment, Exploitation, Properties and Durability". Environmental Earth Sciences, 77, Article No. 730. https://doi.org/10.1007/s12665-018-7755-1

[4] Hatem, A. (2015) Physical and Mechanical Characteristics of Helwan Limestone: For Conservation Treatment of Ancient Egyptian Limestone Monuments. Journal of American Science, 11, 136-149.

[5] Navarro, C. and Doehne, E. (1999) Salt Weathering: The Influence of Evaporation Rate, Supersaturation and Crystallisation Pattern. Earth Surface Processes and Landforms, 24, 191-209. https://doi.org/10.1002/(SICI)1096-9837(199903)24:3<191::AID-ESP942>3.0.CO;2$\underline{\mathrm{G}}$

[6] Charola, E. (2000) Salts in the Deterioration of Porous Materials: An Overview. Journal of the American Institute for Conservation, 39, 327-343. https://doi.org/10.1179/019713600806113176

[7] Figueiredo, C., Folha, R., Maurício, A., Alves, C. and Aires-Barros, L. (2010) Pore Structure and Durability of Portuguese Limestone: A Case Study. Geological Society, London, Special Publications, 331, 157-169. http://dx.doi.org/10.1144/SP331.14

[8] Rodriguez-Navarro, C., Hansen, E., Sebastian, E. and Ginell, W. (1997) The Role of Clays in the Decay of Ancient Egyptian Limestone Sculptures. Journal of the American Institute for Conservation, 36, 151-163. https://doi.org/10.1179/019713697806373172 
[9] Hanna, S. (1984) The Use of Organo-Silanes for the Treatment of Limestone, in Advanced State of Deterioration. Studies in Conservation, 29, 171-176. https://doi.org/10.1179/sic.1984.29.Supplement-1.171

[10] Rodriguez-Navarro, C., Sebastian, E., Doehne, E. and Ginell, W. (1998) The Role of Sepiolite-Palygorskite in the Decay of Ancient Egyptian Limestone Sculptures. Clay and Clay Minerals, 46, 414-422.

[11] Thickett, D., Lee, N. and Bradley, S. (2000) Assessment of the Performance of Silane Treatments Applied to Egyptian Limestone Sculptures Displayed in a Museum Environment. Proceedings of the 9 th International Congress on Deterioration and Conservation of Stone, Venice, 19-24 June 2000, 503-511.

[12] Madsen, F. and Müller-Vonmoos, M. (1989) The Swelling Behaviour of Clays. Applied Clay Science, 4, 143-156. https://doi.org/10.1016/0169-1317(89)90005-7

[13] Sabina, K., Ana, M., Helmut, P. and Breda, M. (2011) Deterioration of the Black Drenov Gric Limestone on Historical Monuments (Ljubljana, Slovenia). Acta Carsologica, 40, 483-495. https://doi.org/10.3986/ac.v40i3.60

[14] Arnold, A. (1976) Behavior of Some Soluble Salts in Stone Deterioration. 2nd International Symposium on the Deterioration of Building Stones, Athens, date, 27-35.

[15] Nord, G. and Tronner, K. (1995) Effect of Acid Rain on Sandstone: The Royal Palace and the Riddarholm Church, Stockholm. Water, Air and Soil Pollution, 85, 2719-2724. https://doi.org/10.1007/BF01186245

[16] Nijland, G., Dubelaar, C.W., Van Hees, R.P.J. and Linden, T.J.M. (2003) Black Weathering of Bentheim and Obernkirchen Sandstone. Heron, 48, 179-195.

[17] Ruedrich, J., et al. (2005) Damage Phenomenon and Salt Deterioration at the Michaelis Church in Zeitz (Germany). Geophysical Research Abstracts, 7, 04488.

[18] Mercedes Perez-Monserrat, E., Jose Varas-Muriel, M., Alvarez De Buergo, M. and Rafael, F. (2016) Limestone as Markers of Environmental Change, Elena Mercedes Perez-Monserrat. Geosciences, 6, 4. https://doi.org/10.3390/geosciences6010004 www.mdpi.com/journal/geosciences

[19] Rothert, E., Eggers, T., Cassar, J., Ruedrich, J., Fitzner, B. and Siegesmund, S. (2007) Stone Properties and Weathering Induced by Salt Crystallization of Maltese Globigerina Limestone. Geological Society, London, Special Publications, 271, 189-198. http://dx.doi.org/10.1144/GSL.SP.2007.271.01.19

[20] El-Gohary, M. (2011) Chemical Deterioration of Egyptian Limestone affected by Saline Water. International Journal of Conservation Science, 2, 17-28.

[21] Hyvert, G. (1978) Weathering and Restoration of Borobudur Temple, Indonesia. Geological Society of America, Engineering Geology Case Histories, 11, 95-100. https://doi.org/10.1130/Eng-Case-11.95

[22] Keller, D. (1978) Progress and Problems in Rock Weathering Related to Stone Decay. Geological Society of America, Engineering Geology Case Histories, 11, 37-46. https://doi.org/10.1130/Eng-Case-11.37

[23] Carlos, R., Eduardo, S., Eric, D. and William, S. (1998) The Role of Sepiolite-Palygorskite in the Decay of Ancient Egyptian Limestone Sculptures. Clays and Clay Minerals, 46, 414-422.

[24] Ercole, C., et al. (2014) Microbial Biotechnologies to Preserve and Restore Stone Monuments. In: Méndez-Vilas, A., Ed., Microscopy: Advances in Scientific Research and Education, Formatex, Badajoz, Spain, 499-456.

[25] Winkler, M. (1998) The Complexity of Urban Stone Decay. Geotimes, 43, 25-29.

[26] Wampler, J.M. (1997) Mythical Influences of Crystallization Temperature and 
Pressure on the Susceptibility of Minerals to Weathering. Journal of Geoscience Education, 45, 74-76. https://doi.org/10.5408/1089-9995-45.1.74

[27] Gauri, L. (1974) Decay and Its Prevention in Natural Stone. Transactions of the Kentucky Academy of Science, 35, 29-36.

[28] Nijland, T. and Van Hees, R. (2009) Salt Decay of Morley Limestone. HERON, 54, 279-289.

[29] Gauri, K.L. (1980) Deterioration of Architectural Structures and Monuments. In: Toribara, T.Y., Miller, M.W., Morrow P.E., Eds., Polluted Rain, Environmental Science Research, Springer, Boston, 125-145. https://doi.org/10.1007/978-1-4613-3060-8 7

[30] Stéphanie, E., Eyssautier, C., Nathalie, V., Maxime, G., Céline, T., Jessica, P. and Gilles, F. (2015) Efficacy of Different Chemical Mixtures against Green Algal Growth on Limestone: A Case Study with Chlorella Vulgaris. International Biodeterioration \& Biodegradation, 103, 59-68. https://doi.org/10.1016/j.ibiod.2015.02.021

[31] Gaylarde, C., Baptista-Neto, J., Ogawa, A., Kowalski, M., Celikkol-Aydin, S. and Beech, I. (2017) Epilithic and Endolithic Microorganisms and Deterioration on Stone Church Facades Subject to Urban Pollution in a Sub-Tropical Climate. Biofouling, 33, 113-127. https://doi.org/10.1080/08927014.2016.1269893

[32] Ahmed, M., Darwish, S., Elmarzugi, N., Al-Dosari, M., Adam, M. and Al-Mouallimi, N. (2016) Evaluation of Photocatalysis TiO2 Nano-Particles as a Self-Cleaning to Calcareous Stone Monuments Surface. 8th International Conference on Nano-Technology in Construction, Sharm El-Sheikh, 12-16 March 2016, 1-12.

[33] Topal, T., Deniz, B. and Güçhan, N. (2015) Decay of Limestone Statues at Mount Nemrut (Adiyaman, Turkey). International Journal of Architectural Heritage, 9, 244-264. https://doi.org/10.1080/15583058.2013.768310

[34] Alenbaawy, A. and Moussa, A. (2011) Characteristics of Building Materials Exposed to Geoenvironmental Impacts in Makaad Radwan, Ottoman Cairo, Egypt. Egyptian Journal of Archaeological and Restoration Studies, 1, 41-51. https://dx.doi.org/10.21608/ejars.2011.7487

[35] Doehne, E. (2002) Salt Weathering: A Selective Review. Geological Society, London, Special Publications, 205, 51-64. http://dx.doi.org/10.1144/GSL.SP.2002.205.01.05

[36] Nunbergand, S. and Charola, A. (2001) Salts on Ceramic Bodies II, Deterioration Due to Minimal Changes in Relative Humidity. Internationale Zeitschrifi fur Bauinsmndsetzen und Baudenkmalpflege, 7, 131-146.

[37] Doehne, E. and Price, C. (2010) Stone Conservation: An Overview of Current Research. Getty Conservation Institute, Los Angeles.

http://www.getty.edu/conservation/publications_resources/pdf_publications/pdf/st oneconservation.pdf

[38] Sawdy, A., Lubelli, B., Voroninaand, V. and Pel, L. (2010) Optimizing the Extraction of Soluble Salts from Porous Materials by Poultices. Studies in Conservation, 55, 26-40. https://doi.org/10.1179/sic.2010.55.1.26

[39] Gänsicke, S., Hatchfield, P., Hykin, A., Svoboda, M. and Tsu, C. (2003) The Ancient Egyptian Collection at the Museum of Fine Arts, Boston Part 2, A Review of Former Treatments at the MFA and Their Consequences. Journal of the American Institute for Conservation, 42, 193-236. https://doi.org/10.2307/3180070

[40] Horie, C. (2006) Materials for Conservation: Organic Consolidants, Adhesives and Coatings. Butterworth-Heinemann, Oxford.

[41] Brus, J. and Kotlík, P. (1996) Consolidation of Stone by Mixtures of Alkoxysilane 
and Acrylic Polymer. Studies in Conservation, 41, 109-119. https://doi.org/10.1179/sic.1996.41.2.109

[42] Wheeler, G., Mendez-Vivar, J., Goins, E., Fleming, S. and Brinker, C. (2000) Evaluation of Alkoxysilane Coupling Agents in the Consolidation of Limestone. 9th International Congress on Deterioration and Conservation of Stone, Venice, June 19-24 2000, 541-545.

[43] Scherer, G. and Wheeler, G. (2009) Silicate Consolidants for Stone. Key Engineering Materials, 391, 1-25. https://doi.org/10.4028/www.scientific.net/KEM.391.1

[44] Grissom, C., Charola, E., Boultonand, A. and Mecklenburg, M. (1999) Evaluation over Time of an Ethyl Silicate Consolidant Applied to Ancient Lime Plaster. Studies in Conservation, 44, 113-120. https://doi.org/10.1179/sic.1999.44.2.113

[45] Wheeler, G., Dinsmore, J., Ransick, L., Charola, A. and Koestler, R. (1984) Treatment of the Abydos Reliefs: Consolidation and Cleaning. Studies in Conservation, 29, 42-48. https://doi.org/10.1179/sic.1984.29.1.42

[46] Wheeler, G. (2005) Alkoxysilanes and the Consolidation of Stone. Getty Publications, Los Angeles.

[47] Vergès-Belmin, V. and Siedel, H. (2005) Desalination of Masonries and Monumental Sculptures by Poulticing, Restoration of Buildings and Monuments. Bauinstandsetzen und Baudenkmalpflege, 11, 391-408.

https://doi.org/10.1515/rbm-2005-6000 